\title{
Sistem Informasi Monitoring Wiraniaga
}

\author{
(Studi kasus di UD. Super Dangsul)
}

\author{
Kholid Haryono \\ Jurusan Informatika, Fakultas \\ Teknologi Industri, \\ Universitas Islam Indonesia \\ Jl. Kaliurang KM 14.5 \\ Yogyakarta \\ kholid.haryono@uii.ac.id
}

\author{
Fahmy Abida Asa Firdausi \\ Jurusan Informatika, Fakultas \\ Teknologi Industri, \\ Universitas Islam Indonesia \\ Jl. Kaliurang KM 14.5 \\ Yogyakarta \\ fahmyabida@gmail.com
}

\author{
Hendrik \\ Jurusan Informatika, Fakultas \\ Teknologi Industri, \\ Universitas Islam Indonesia \\ J1. Kaliurang KM 14.5 \\ Yogyakarta \\ hendrik@uii.ac.id
}

\begin{abstract}
Abstrak-UD. Super Dangsul merupakan pabrik tempe yang berdiri sejak tahun 1998 dengan karyawan sebanyak 20 orang dan sales 30 orang. Pabrik berlokasi di Yogyakarta ini mampu menghabiskan 1,2 ton kedelai untuk memproduksi. Sales adalah seseorang dibagian pemasaran dan merupakan pekerja lepas yang berada di luar lingkup pengawasan langsung dari pemilik. Seiring jumlah permintaan produk yang meningkat, dibutuhkan lebih banyak sales untuk mendistribusikan produk. Pada bagian pemasaran ini sering terjadi kecurangan yang dapat menimbulkan kerugian produksi. Kecurangan ini mengakibatkan perusahaan pernah mengalami kehilangan konsumen. Berdasarkan permasalahan yang ada maka peneliti mengusulkan sebuah sistem informasi yang dapat mempermudah pengelolaan dan pengawasan sales. Penelitian dimulai dari kajian pustaka, analisis kebutuhan, implementasi skenario, dan diuji menggunakan UAT (User Acceptance Testing) dan uji fungsional. Fungsi utama sistem telah dapat memberikan kemudahan pengelolaan sales. Sistem juga mampu melakukan monitoring aktifitas dan pengawasan terhadap sales dari kecurangan yang dapat mengakibatkan memburuknya nama baik perusahaan.
\end{abstract}

Kata kunci_-sistem informasi; sistem monitoring; kecurangan transaksi; uji fungsional; UAT

\section{PENDAHULUAN}

Berdasarkan Badan Standar Nasional (BSN) tahun 2012 bahwa konsumsi tempe rata-rata per orang per tahun di Indonesia saat ini mencapai sekitar 6,45 kg [1]. Jika menggunakan data penduduk Indonesia tahun 2013 adalah 249.9 juta jiwa, usia produktif makan tempe adalah 50\% dari jumlah tersebut yakni 124 juta jiwa maka kebutuhan tempe mencapai $805,927,500 \mathrm{Kg}$ per tahun. Kebutuhan sangat besar dan membutuhkan produsen yang dapat memenuhi permintaan.

UD Super Dangsul adalah salah satu produsen tempe di provinsi D.I Yogyakarta. Perusahaan ini berdiri sejak tahun 1998 dan memiliki banyak pelanggan fanatik di wilayah DIY. Dalam sehari industri ini mampu menghabiskan 1,2 ton kedelai untuk keperluan produksi. Saat ini, produksi dan pemasaran dikerjakan oleh 20 orang karyawan bagian produksi dan 30 orang sales pemasaran.

Sales merupakan pekerja lepas yang berada di luar lingkup pengawasan langsung dari pemilik. Sales lepas yang melakukan penjualan langsung kepada konsumen menurut Kamus Besar Bahasa Indonesia (KBBI daring) disebut juga wiraniaga [2]. Perusahaan menunjuk seorang staf yang bertindak selaku pengepul untuk mengelola sales. Untuk memenuhi permintaah yang terus meningkat, dibutuhkan banyak sales. Pengelolaan sales yang saat ini menggunakan pencatatan sederhana sering menimbulkan kesalah fahaman terutama pada proses pemesanan, pengambilan produk, dan setoran hasil distribusi. Pada bagian pemasaran ini juga sering terjadi kecurangan yang dapat menimbulkan kerugian perusahaan. Salah satu jenis kecurangan yang sering terjadi adalah permainan harga yang dilakukan oleh oknum sales padahal harga telah ditentukan oleh perusahaan. Mereka memanfaatkan tingginya permintaan sebagai kesempatan. Kecurangan ini mengakibatkan perusahaan pernah mengalami kehilangan beberapa konsumen setia. Belum ada mekanisme dan sistem yang mampu menangani jumlah sales dan praktik-praktik kecurangan secara baik.

Berdasarkan permasalahan yang terjadi maka peneliti mengusulkan sistem informasi monitoring wiraniaga yang mampu mengelola dan melakukan pengawasan kepada seluruh sales agar reputasi perusahaan terus terjaga. Sistem ini diharapkan mampu membantu pemilik untuk dapat mengelola perusahaan semakin efektif dan efisien terutama untuk mengelola berapapun jumlah sales yang nantinya akan dipekerjakan. Kontribusi penelitian adalah pelajaran yang dapat dipetik dari temuan yang didapat pada setiap tahap pengembangan hingga implementasi.. 


\section{METODE}

Untuk menyelesaikan dua masalah utama penelitian ini, yakni pertama pengelolaan sales yang banyak dan cenderung meningkat, kedua memberikan kemudahan pengawasan terhadap sales dari praktik-praktik curang yang dapat menimbulkan hilangnya kepercayaan pelanggan, maka langkah-langkah yang dilakukan adalah: (a) wawancara kepada pemilik; (b) observasi untuk mengamati pengelolaan dilapangan; (c) pengumpulan dokumen operasional perusahaan; (d) tahapan perancangan sistem menggunakan general SDLC [3][4] yang dimulai tahap analisis kebutuhan, perancangan, implementasi, dan pengujian sistem.

\section{A. Wawancara pemilik}

Tahap ini paling penting untuk menentukan masalah utama yang dihadapi pemilik. Hal ini untuk menentukan spesifikasi kebutuhan dan harapan pemilik. Dari hasil wawancara, didapatkan dua hal penting yakni pertama meningkatnya animo masyarakat terhadap produk menuntut pemilik agar dapat meningkatkan jumlah sales. Pengelolaan sales sulit dilakukan karena mereka pekerja lepas yang kapan saja bisa keluar masuk. Dibutuhkan sistem yang dapat berkomunikasi secara otomatis pada setiap proses kerja sales mulai dari permintaan hingga setoran akhir. Pembukuan sederhana sering menimbulkan kesalahan terutama terkait dengan jumlah produk yang dipesan, jenis produk yang salah ambil, dan setoran yang kurang. Hal ini menimbulkan ketidaknyamanan sales, padahal mereka adalah ujung tombak dari perusahaan.

Kedua terjadinya kecurangan yang dilakukan oleh oknum sales dengan memainkan harga ke konsumen. Akibatnya beberapa konsumen setia meninggalkan perusahaan dan beralih ke kompetitor. Pemilik membutuhkan sistem yang mampu mengawasi kinerja sales dalam hal kontrol terjadinya kecurangan. $\mathrm{s}$

\section{B. Observasi}

Merupakan tahap melakukan pengamatan terhadap praktik yang sekarang terjadi. Pengamatan penting untuk melihat celah terjadinya persoalan. Berdasarkan pengamatan langsung yang dilakukan dengan menemani petugas pengepul dan pemilik setiap transaksi harian terjadi, proses yang terjadi adalah setiap hari sales memesan berbagai jenis produk berikut jumlahnya. Pesanan ini digunakan oleh pemilik untuk memprediksi jumlah yang diproduksi esok hari, pemesanan dilakukan dengan menulis pada buku besar dan masih bisa di ubah dengan mengirim pesan elektronik, titip pesan teman sales lain, atau via telpon.

Pagi hari sales mengambil produk sesuai yang dipesan baik jumlah maupun jenisnya. Beberapa terjadi perselisihan karena perbedaan jumlah setiap jenis yang diambil, hal ini karena adanya perubahan pesanan yang dilakukan dan tidak tercatat secara rapi sehingga petugas yang mempersiapkan dipagi hari mengacu data pesanan yang berbeda. Sekaligus mengambil barang, sales juga memesan untuk esok harinya. Pada sore/malam hari, sales datang melaporkan setoran dan informasi sisa produk yang tidak laku. Perbedaan jumlah pengambilan, sisa yang disetorkan, dan produk yang diakui terjual kerap menimbulkan disharmoni antara perusahaan dan sales.

Beberapa laporan pengaduan telah masuk melalui sales dan pelanggan kepada pemilik terutama terkait jumlah pesanan pelanggan kepada sales diantarnya kurang dari jumlah yang dipesan. Ada pelanggan yang lapor harga naik sampai dua kali lipat meskipun tidak ada kenaikan yang ditentukan oleh perusahaan. Ada sales yang mengirim produk lain kepada pelanggan. Beberapa temuan observasi ini menjadi masukan desain sistem yang dibutuhkan.

\section{Pengumpulan dokumen}

Dokumen operasional yang dilakuan dengan pembukuan sederhana dipelajari untuk memahami proses yang terjadi. Dokumen ini menunjukkan lemahnya pencatatan dan terkesan hanya formalitas karena sulit dibaca dan sering terjadi kesalahan baca dari petugas-petugas di lapangan. Dokumen ini meliputi catatan pemesanan, catatan produksi, dokumen pembayaran dan setoran, laporan harian, dan laporan kecurangan yang dilaporkan oleh sales dan pelanggan. Temuan pada tahap ini digunakan untuk mencari fitur sistem yang sesuai.

\section{Perancangan}

Berdasarkan general SDLC terdapat empat aktifitas utama yakni analisis kebutuhan, analisis desain, implementasi, dan pengujian sistem. Analisis kebutuhan dibagi menjadi empat yaitu analisis kebutuhan pengguna; analisis kebutuhan fungsional; analisis kebutuhan antarmuka; dan analisis kebutuhan desain.

\section{Analisis kebutuhan pengguna}

Terdapat dua kebutuhan yang diidentifikasi yakni kebutuhan pengguna dan kebutuhan fungsional. Kebutuhan pengguna teridentifikasi tiga pihak yakni pengepul adalah seseorang yang berperan dalam mengelola permintaan, pengambilan dan setoran produk oleh sales. Kedua adalah pemilik, orang yang memiliki hak akses 
penuh terhadap sistem website dan aplikasi monitoring. Ketiga adalah sales, seseorang yang berhubungan langsung dengan konsumen dan melakukan jual beli produk.

2. Kebutuhan Fungsional

Pengepul secara fungsional melakukan aktifitas-aktifitas sebagai berikut: (a) melayani dan mem-validasi permintaan produk dari sales. (b) melayani pencatatan pengambilan penjualan sales. (c) melayani pencatatan setoran penjualan sales. (d) melakukan pengecekan dan rekap terhadap sales yang berhutang.

Pemilik (Owner) secara fungsional melakukan beberapa aktifitas, yaitu (a) melakukan pengecekan penjualan. (b) melakukan pengecekan terhadap sales yang berhutang. (c) melakukan pengecekan laporan kecurangan oleh sales. (d) melakukan registrasi sales dan admin.

Sales secara fungsional melakukan beberapa aktifitas, yaitu (a) melakukan permintaan produk kepada pengepul/admin. (b) melaporkan kecurangan yang dilakukan oleh oknum sales yang melanggar peraturan jualbeli dan berpotensi merugikan perusahaan dengan hilangnya kepercayaan pelanggan kepada perusahaan.

\section{Kebutuhan Antarmuka}

Berdasarkan karakter transaksinya, terdapat dua kebutuhan antarmuka. Pertama, kebutuhan administratif dan monitoring umum menggunakan laptop (layar lebar). Aktifitasnya dapat dilakukan baik di meja administrasi maupun secara mobile (pemilik). Untuk karakter kebutuhan ini dibutuhkan antarmuka berbasis web yang dapat dibuka menggunakan layar lebar dan tidak terikat ruang dan waktu. Artinya dapat dilayani dimana saja dan kapan saja selama memiliki koneksi internet. Kedua kebutuhan pemesanan dan laporan sales yang mobile dan melekat pada gawai yang dipegang oleh sales. Sistem sales dibuat berbasis android. Basis android dipilih karena semua sales menggunakan gawai dengan sistem operasi ini.

\section{Analisis desain}

Dalam perancangan sistem, metode yang digunakan adalah metode perancangan berorientasi objek dengan menggunakan UML (Unified Modeling Language). Bentuk UML yang digunakan adalah Usecase diagram dan activity diagram. Berdasarkan basis pengembangannya, usecase diagram yang dibuat ada dua yaitu diagram untuk sistem berbasis android dan diagram berbasis web. Untuk diagram berbasis android ditunjukkan pada Gambar 1, dan diagram berbasis web ditunjukkan pada Gambar 2.

\section{A. Usecase Diagram}

\section{1) Usecase Diagram basis Android}

Terdapat dua aktor pada Usecase sistem berbasis android yaitu sales dan pemilik. Aktor sales harus melakukan login untuk mengakses system. Proses-proses yang dapat dilakukan oleh sales adalah input permintaan produk, melihat setoran penjualan individu, dan input laporan kecurangan. Aktor pemilik juga harus melakukan login untuk melihat hasil penjualan produk seluruh sales.

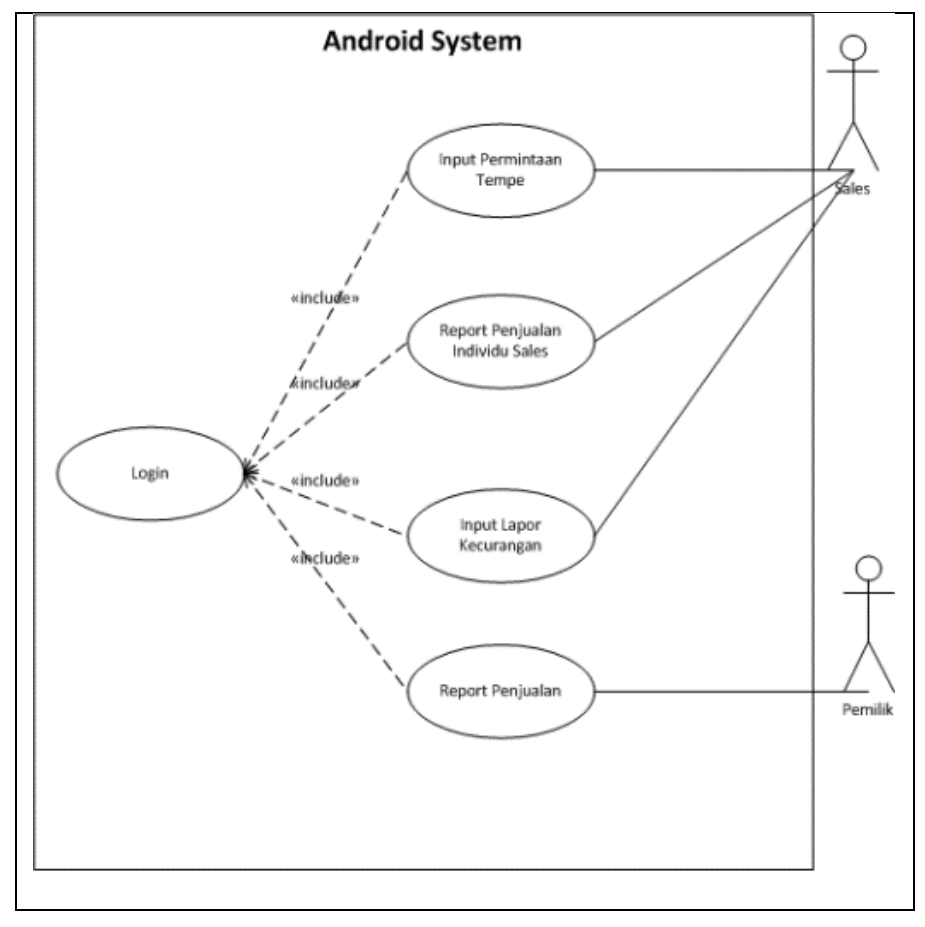


2) Use Case Diagram basis Website

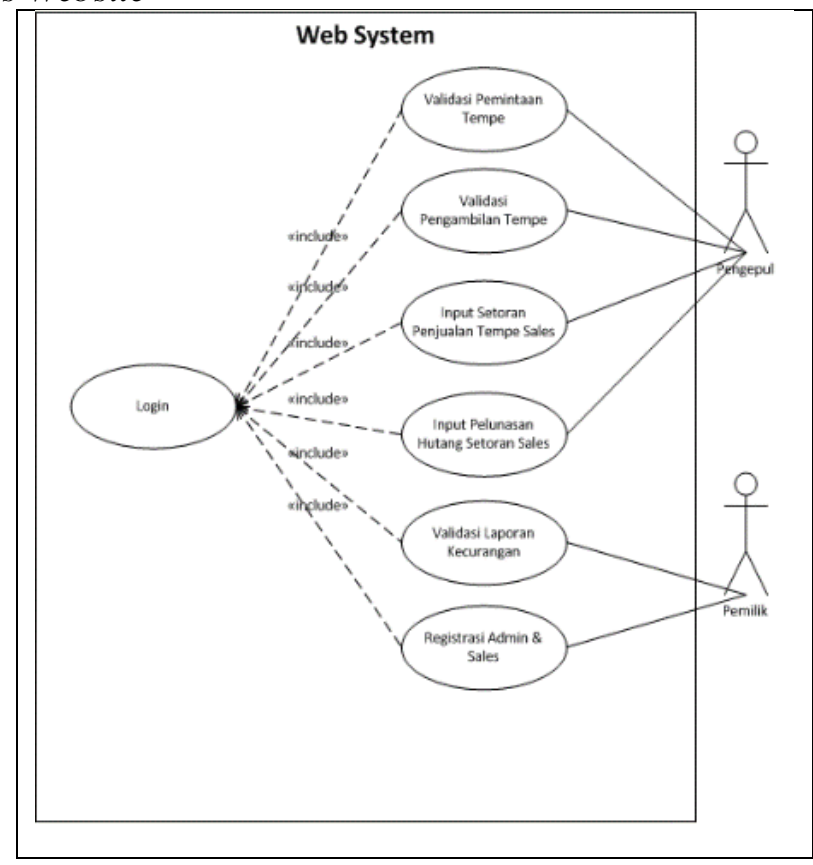

Gambar 2. Usecase Diagram pada Website

Terdapat dua aktor pada usecase sistem berbasis web, yakni aktor pengepul dan pemilik. Aktor pengepul dapat mem-validasi permintaan produk, mem-validasi pengambilan produk dan melakukan input pelunasan hutang. Aktor pemilik pada basis ini dapat melakukan validasi laporan kecurangan dan registrasi user admin dan sales.

\section{B. Activity Diagram}

Activity diagram digunakan untuk menjelaskan spesifikasi detail dari setiap use case diagram dengan menjelaskan alur aktivitas yang dilakukan oleh aktor dalam mengakses fungsionalitas pada sistem. Activity diagram untuk input permintaan produk ditunjukkan pada Gambar 3.

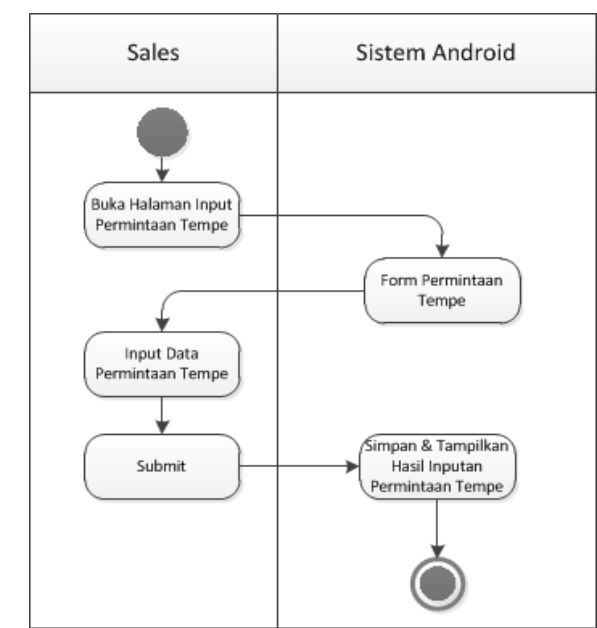

Gambar 3. Activity Diagram Input Permintaan Produk

Gambar 3 menjelaskan urutan proses yang dilakukan oleh sales ketika memesan permintaan produk. Dimulai dari sales membuka form permintaan, sistem menampilkan form, sales mengisi form sesuai dengan data yang diminta, dan terakhir menyimpan/submit pesanan dengan klik tombol submit. Pesanan ini akan masuk ke 
dashboardnya pengepul. Selanjutnya pengepul melakukan validasi permintaan produk. Activity diagram validasi permintaan produk ditunjukkan pada Gambar 4.

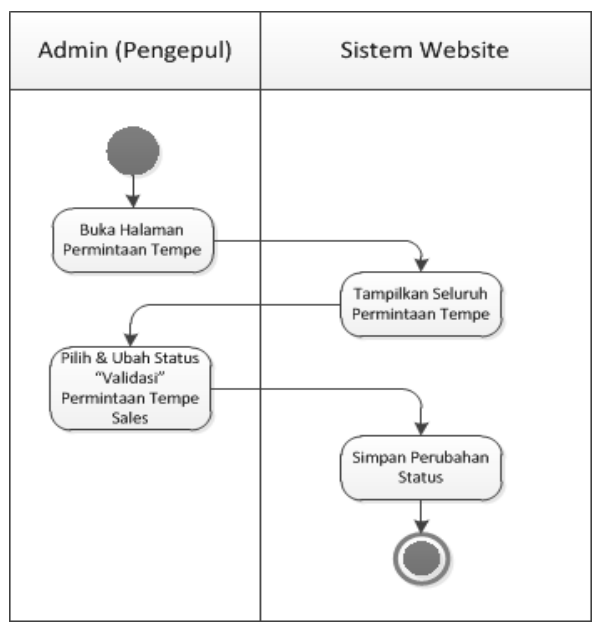

Gambar 4. Activity Diagram Validasi Permintaan Tempe

Gambar 4 adalah proses pengepul melakukan validasi atas permintaan pesanan dari sales. Pengepul membuka detil pesanan sales dan mengubah status pesanan menjadi tervalidasi. Semua proses tersebut dilakukan satu hari sebelum produk diambil. Pada pagi hari, sales mengambil produk yang telah dipersiapkan oleh pengepul sesuai dengan pesanan hari sebelumnya. Activity diagram pengambilan produk ditunjukkan pada Gambar 5.

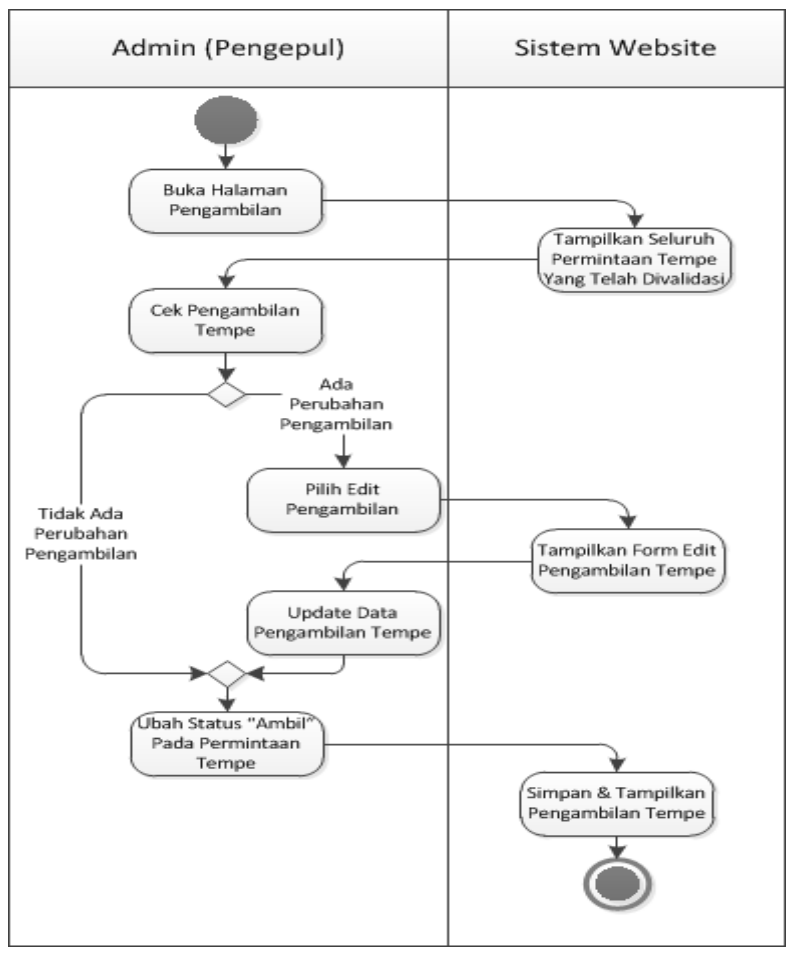

Gambar 5. Activity Diagram Validasi Pengambilan Tempe

Proses pengambilan produk pada Gambar 5 menunjukkan bahwa jumlah yang diambil dapat diedit sesuai dengan ketersediaan produk dan kebutuhan sales. Jika tidak ada perubahan makan proses hanya akan merubah status menjadi "Ambil", sedangkan jika ada perubahan maka pengepul merubah jumlah yang diambil kemudian melakukan validasi. Setelah di-validasi, sales mengirimkan produk ke pemesan (end customer), ke pasar, atau warung-warung. Sore atau malam hari (sebelum pengambilan esok hari), sales harus melakukan setoran hasil penjualannya ke pengepul. Secara fisik yang dilakukan oleh sales adalah mengakui jumlah produk terjual, membayar sejumlah barang yang diakui terjual. Jika jumlah yang dibayar kurang dari seharusnya akan otomatis dicatat sebagai hutang sales. Dan terakhir mengembalikan sisa produk yang tidak laku. Activity diagram input setoran penjualan ditunjukkan pada Gambar 6. 


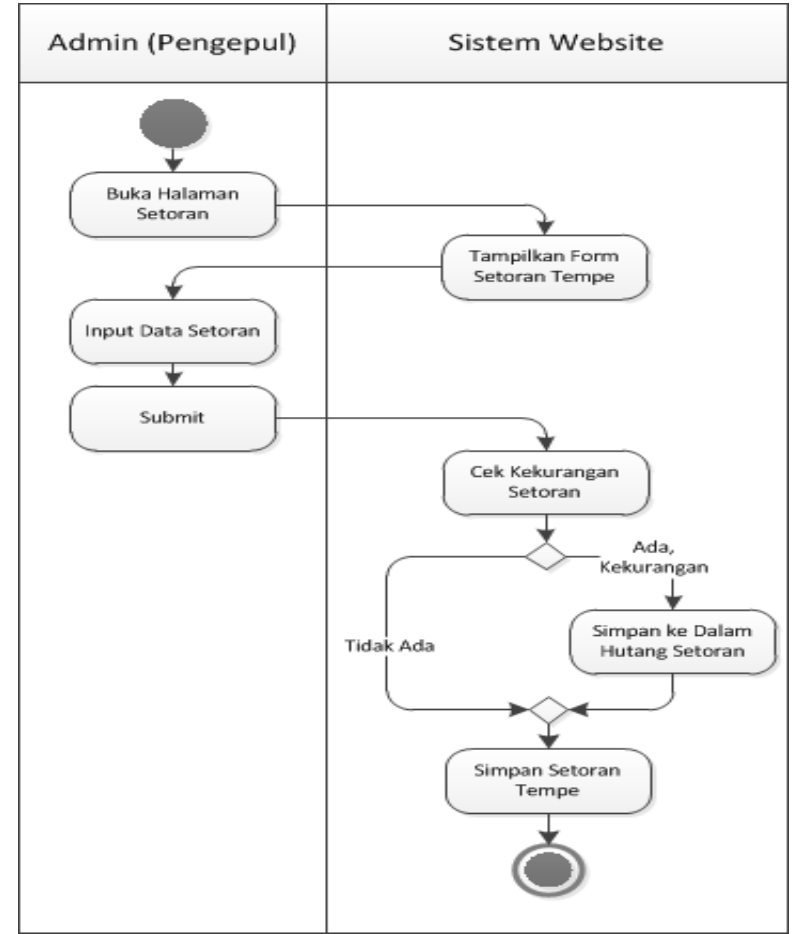

Gambar 6. Activity Diagram Input Setoran Penjualan

Setoran penjualan yang ditunjukkan pada Gambar 6 dimulai dari tampilan form setoran. Jika ada tagihan/hutang sebelumnya akan diinformasikan jumlah yang belum dibayar pada periode sebelumnya. Setoran yang diinput bukan jumlah rupiah akan tetapi jumlah item produk yang terjual, sistem akan otomatis menghitung jumlah rupiah yang ditagihkan. Pengepul memasukkan nilai uang yang diterima dan dimasukkan ke sistem. Jika jumlah kurang dari total tagihan akan dicatat sebagai tambahan hutang. Informasi tentang hutang pada proses ini sangat penting untuk mengendalikan hutang yang berlebihan.

C. Perancangan Basis Data

Perancangan basis data merupakan bagian dari proses pembangunan sistem. Basis data digunakan untuk menyimpan data dari sistem aplikasi monitoring wiraniaga. Struktur dan relasi tabel yang digunakan pada sistem ditunjukkan pada Gambar 7.

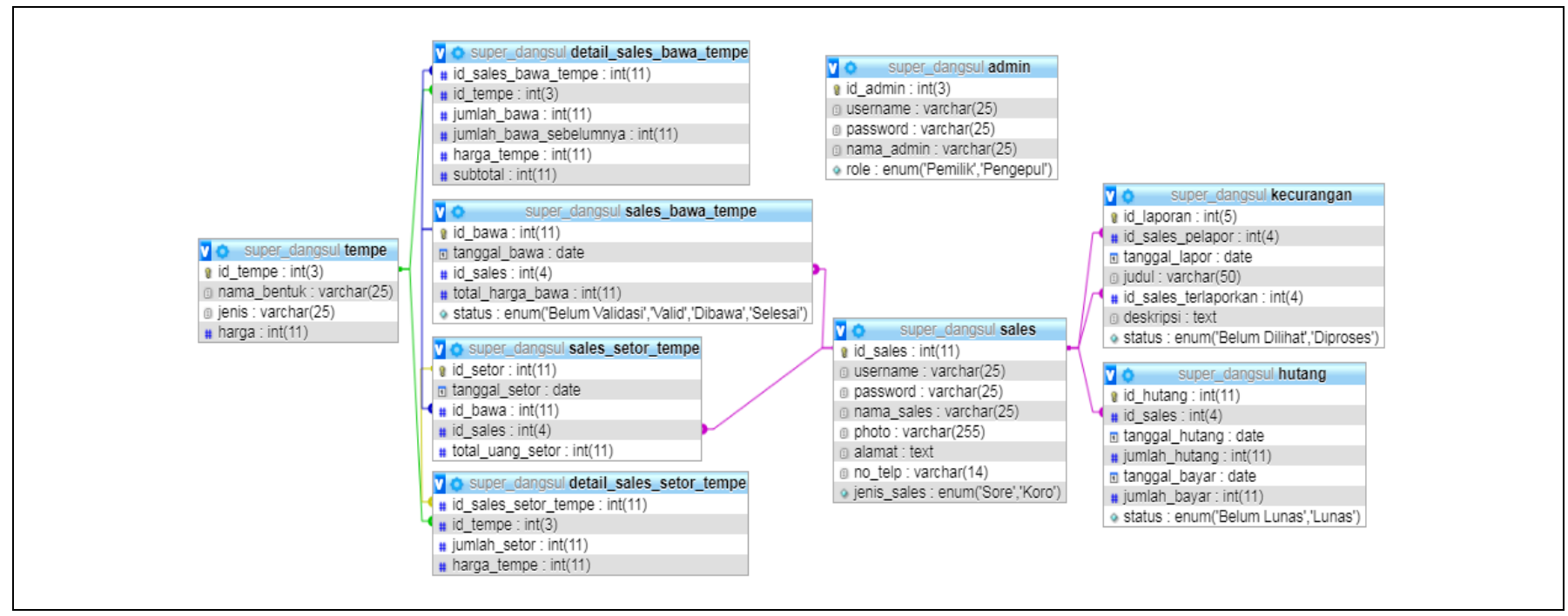

Gambar 7. Struktur dan Relas Tabel

Terdapat 9 tabel yang digunakan untuk mengolah proses-proses yang terjadi sehingga menjadi informasi yang dapat digunakan oleh pemilik perusahaan. Tabel-tabel tersebut diakses oleh aplikasi web dan mobile secara terpusat. Fungsi setiap tabel dan aplikasi yang mengakses ditunjukkan pada Tabel 1. 
TABEL 1. DAFTAR TABEL DAN FUNGSINYA

\begin{tabular}{|c|c|c|}
\hline & Nama tabel & Deskripsi \\
\hline 1 & Tempe & Data master untuk menyimpan identitas produk \\
\hline 2 & Sales_bawa_tempe & $\begin{array}{l}\text { Menyimpan data induk transaksi pengambilan } \\
\text { produk berdasarkan order hari sebelumnya }\end{array}$ \\
\hline 3 & Detail_sales_bawa_tempe & Menyimpan item produk yang diambi. \\
\hline 4 & Sales_setor_tempe & $\begin{array}{l}\text { Menyimpan data induk transaksi setor uang dari item } \\
\text { produk yang terjual dan melaporkan sisa produk } \\
\text { yang tidak laku }\end{array}$ \\
\hline 5 & Detail_sales_setor_tempe & $\begin{array}{l}\text { Menyimpan data sisa produk yang telah diambil dan } \\
\text { tidak laku. }\end{array}$ \\
\hline 6 & Sales & $\begin{array}{l}\text { Menyimpan data master sales yang mencatat } \\
\text { identitas. Data ini digunakan sebagai referensi dari } \\
\text { tabel-tabel transaksi yang berelasi. }\end{array}$ \\
\hline 7 & Kecurangan & $\begin{array}{l}\text { Menyimpan data laporan kecurangan dan status } \\
\text { followup dari setiap laporan. }\end{array}$ \\
\hline 8 & Hutang & $\begin{array}{l}\text { Menyimpan data kekurangan setoran. Misalnya jika } \\
\text { total nilai produk laku adalah } \mathrm{Rp} 250,000 \text { dan sales } \\
\text { menyetorkan Rp } 200,000 \text { maka sistem secara } \\
\text { otomatis mencatat selisihnya sebagai hutang. }\end{array}$ \\
\hline 9 & Admin & $\begin{array}{l}\text { Tabel yang digunakan untuk menyimpan identitas } \\
\text { karyawan berikut data login untuk mengamankan } \\
\text { sistem dari campurtangan pihak luar. }\end{array}$ \\
\hline
\end{tabular}

Tabel yang secara khusus digunakan untuk transaksi mobile adalah tabel Sales_bawa_tempe, Detail_sales_bawa_tempe, Sales_setor_tempe, dan Detail_sales_setor_tempe. Tabel tersebut menyimpan data transaksi utama yang akan diolah oleh sistem menjadi kontrol dalam pengelolaan inventori produk yang dikelola.

\section{IMPLEMENTASI DAN PENGUJIAN}

Implementasi sistem menjelaskan tentang hasil yang diperoleh dari tahapan sebelumnya, tahap perancangan sistem. Untuk mempermudah pembahasan, implementasi pengujian menggunakan teknik skenario sesuai dengan peran masing-masing user. Terdapat empat skenario (1) skenario permintaan produk, (2) skenario pengambilan produk, (3) skenario setoran penjualan, dan (4) skenario pelaporan kecurangan.

\section{A. Implementasi}

1. Skenario Permintaan Produk

Menunjukkan arus permintaan yang dilakukan oleh sales menggunakan aplikasi mobile dengan gawai. Proses dimulai dari input pemesanan produk, sistem menyimpan ke database dengan status 'belum valid, admin melakukan validasi pemesanan dan mengirimkan notifikasi validasi kepada sales bahwa pesanan telah divalidasi sehingga sales dapat memantau apakah order sudah diterima atau belum. Perubahan jumlah dan item produk yang diorder tidak boleh diganti setelah admin melakukan validasi. Jika terpaksa ada perubahan, sales menghubungi admin via email agar dapat membuka status validasi dan sales dapat melakukan perubahan. Permintaan perubahan melalui sms atau WA tidak diperkenankan karena susah dikelola sedangkan via email lebih mudah karena terdokumentasi dengan baik dan jika sewaktu-waktu terjadi komplain dapat digunakan sebagai bukti. Proses tersebut ditunjukkan pada Gambar 8 


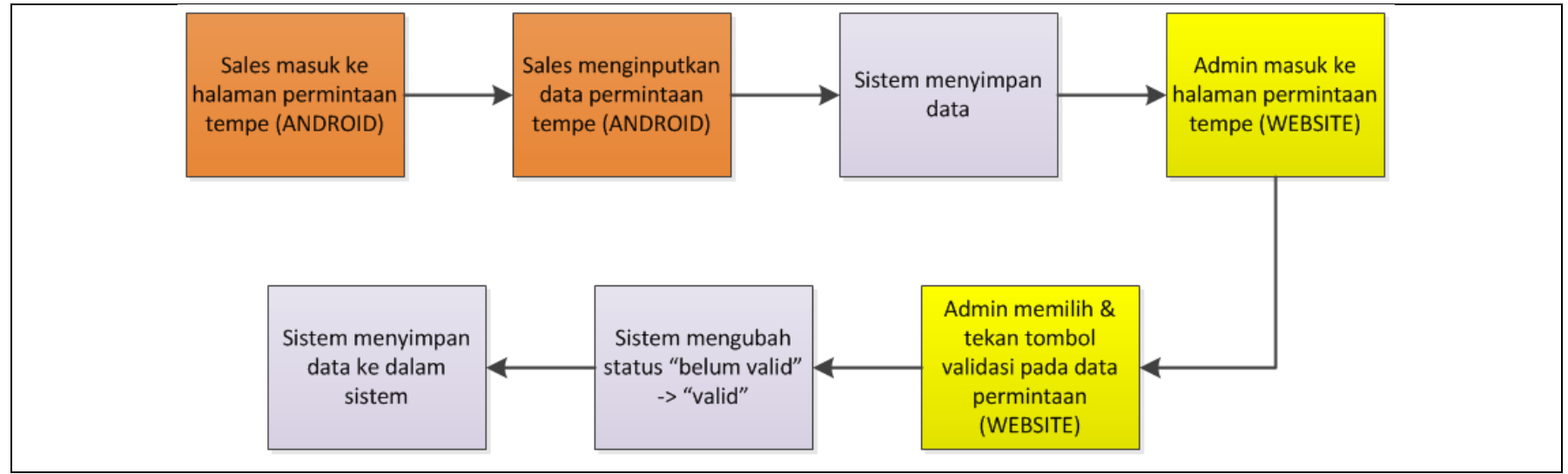

Gambar 8. Skenario permintaan produk

2. Skenario pengambilan produk

Pengambilan produk dilakukan setiap pagi. Petugas mempersiapkan produk yang telah dikelompokkan berdasarkan pesanan sales yang telah divalidasi. Sales mengambil produk berdasarkan jenis dan jumlah yang dipesan. Admin melakukan pengecekan saat proses pengambilan dan mengubah status validasi menjadi status ambil untuk produk yang telah keluar. Sales dapat notifikasi bahwa pesanan telah diambil. Notifikasi digunakan untuk memastikan sekaligus verifikasi bahwa jumlah yang diambil sesuai dengan order yang telah divalidasi sebelumnya. Skenario tersebut ditunjukkan pada Gambar 9

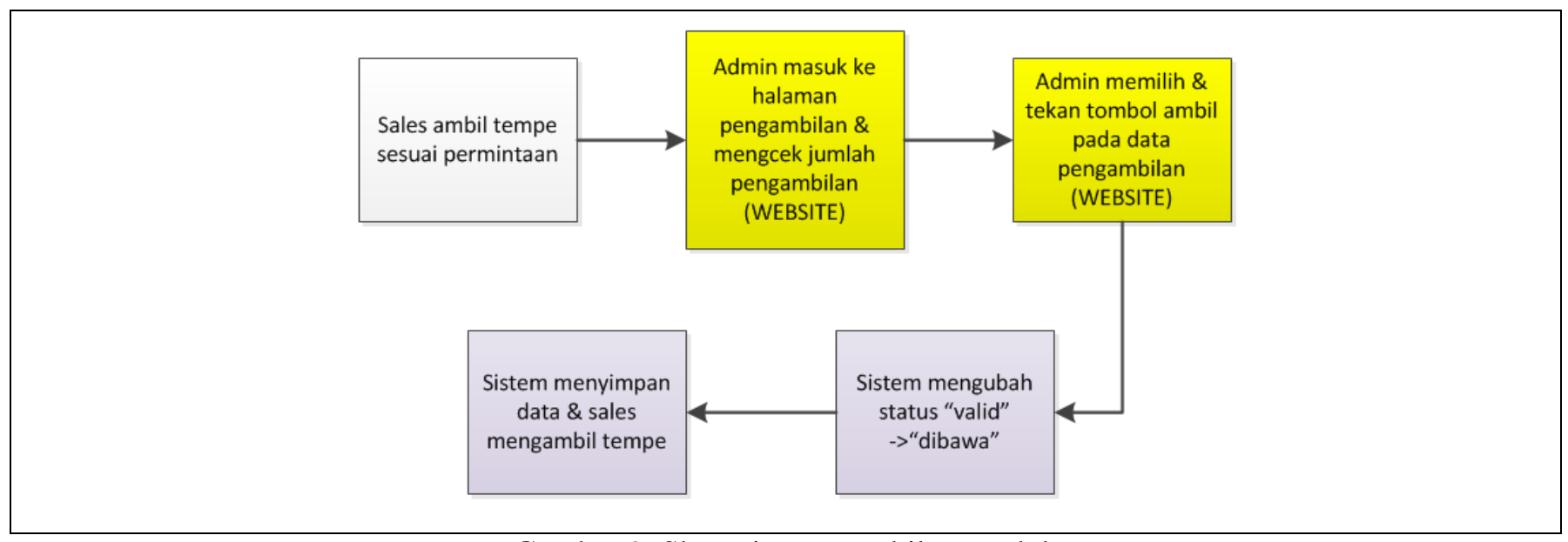

Gambar 9. Skenario pengambilan produk

3. Skenario pengambilan produk

Proses ini dilakukan setiap sore/malam hari setelah sales mendistribusikan produknya. Sales melaporkan berapa yang terjual dan mengembalikan sisa produk. Jumlah sisa dan terjual harus sama dengan jumlah pengambilan. Jumlah yang harus disetor adalah selisih antara produk yang diambil dan dikembalikan menjadi tagihan pembayaran bagi sales. Pembayaran dapat dilakukan kurang dari yang ditagihkan dan akan masuk pos hutang setiap sales. Hutang bisa dibayarkan bertahap sesuai kemampuan. Mekanisme ini dilakukan untuk menjaga kepercayaan dan loyalitas sales kepada perusahaan. Skenario setoran ditunjukkan pada Gambar 10 


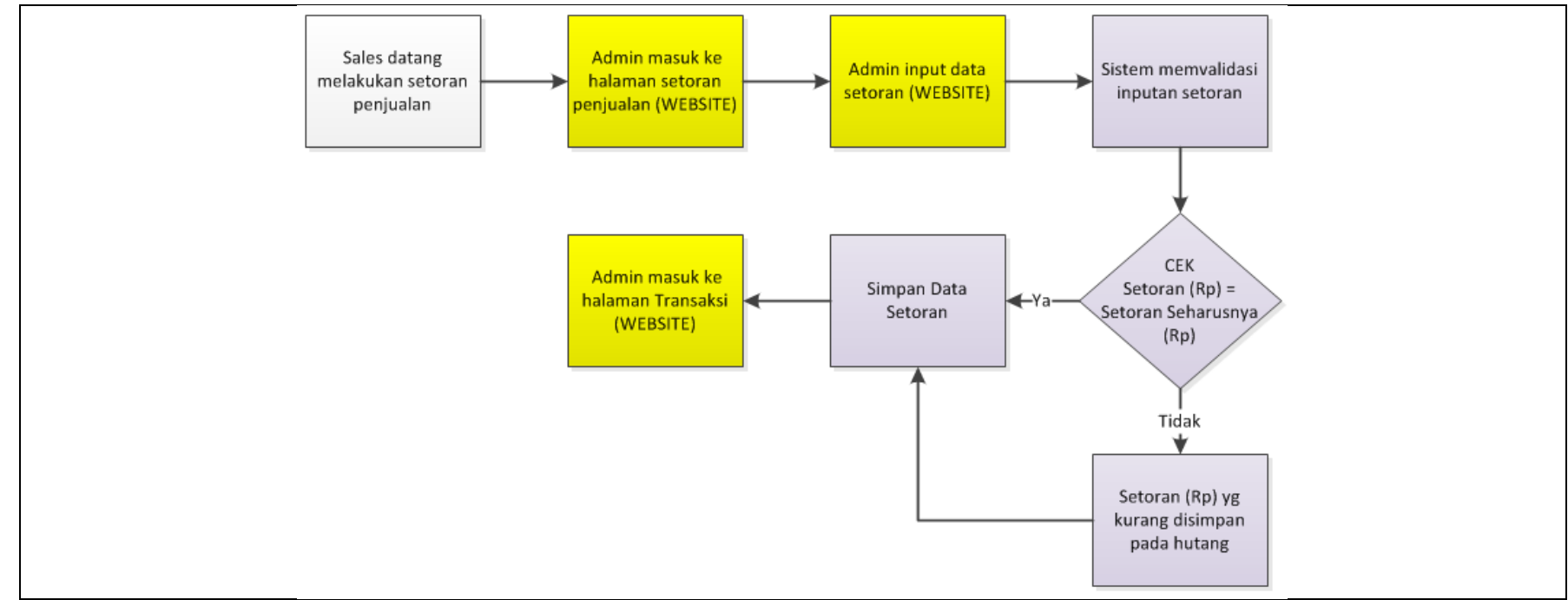

Gambar 10. Skenario setoran penjualan

4. Skenario pelaporan kecurangan

Fitur pelaporan digunakan untuk mengendalikan sales dari praktik-praktik kecurangan yang mengakibatkan hilangnya kepercayaan pelanggan. Melalui akun login masing-masing sales dapat melaporkan rekan lainnya jika melakukan/dicurigai melakukan kecurangan. Laporan secara langsung dilihat oleh pemilik dan diubah statusnya menjadi 'diproses'. Setelah ada tindakan maka status akan diubah menjadi telah ditindak lanjuti. Kepastian setiap laporan ditindak lanjuti membuat sales pelapor lebih perduli terhadap perusahaan meskipun belum sampai diberikan reward. Data yang telah masuk dan statistik laporan dan tindakan kemudian dijadikan rujukan membuat aturan terkait reward dan punishment mengenai pelanggaran maupun bagi pelapor.

5. Antarmuka

Pada bagian ini ditunjukkan empat antarmuka utama terkait dengan skenario untuk menunjukkan gambaran proses yang terjadi.

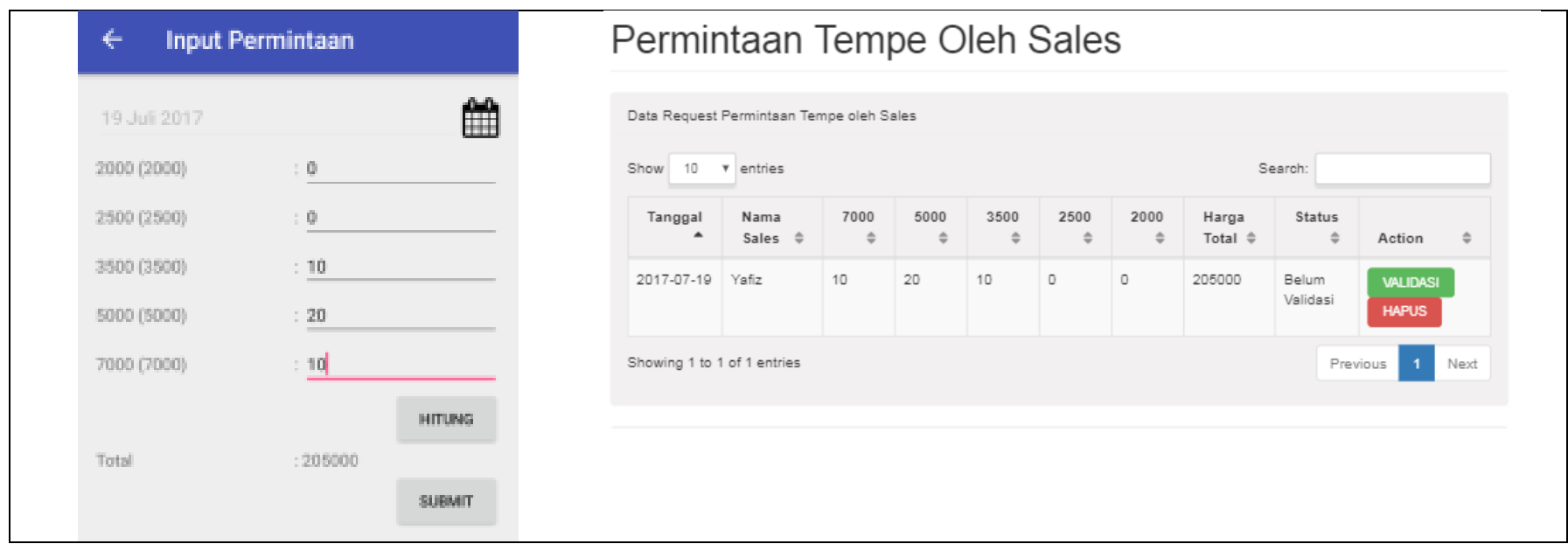

\section{Gambar 11. Antarmuka permintaan produk}

Form dibagi menjadi dua bagian. Bagian input dan daftar transaksi. Karena ragam produk tidak terlalu banyak, untuk mempermudah pengisian ditampilkan seluruh item baik yang akan dipesan maupun tidak. User hanyak mengisi jumlah yang dipesan maka total nilai produk yang diambil akan muncul. Nilai ini penting sebagai gambaran total tagihan yang akan dibebankan kepadanya jika seluruh produk laku. Pada bagian kanan daftar permintaan terdapat dua tombol yakni validasi dan hapus. Validasi digunakan oleh admin sebagai notifikasi dan pengunci untuk sales bahwa order telah diterima dengan jumlah tertentu. Pengambilan produk ditunjukkan pada Gambar 12. 


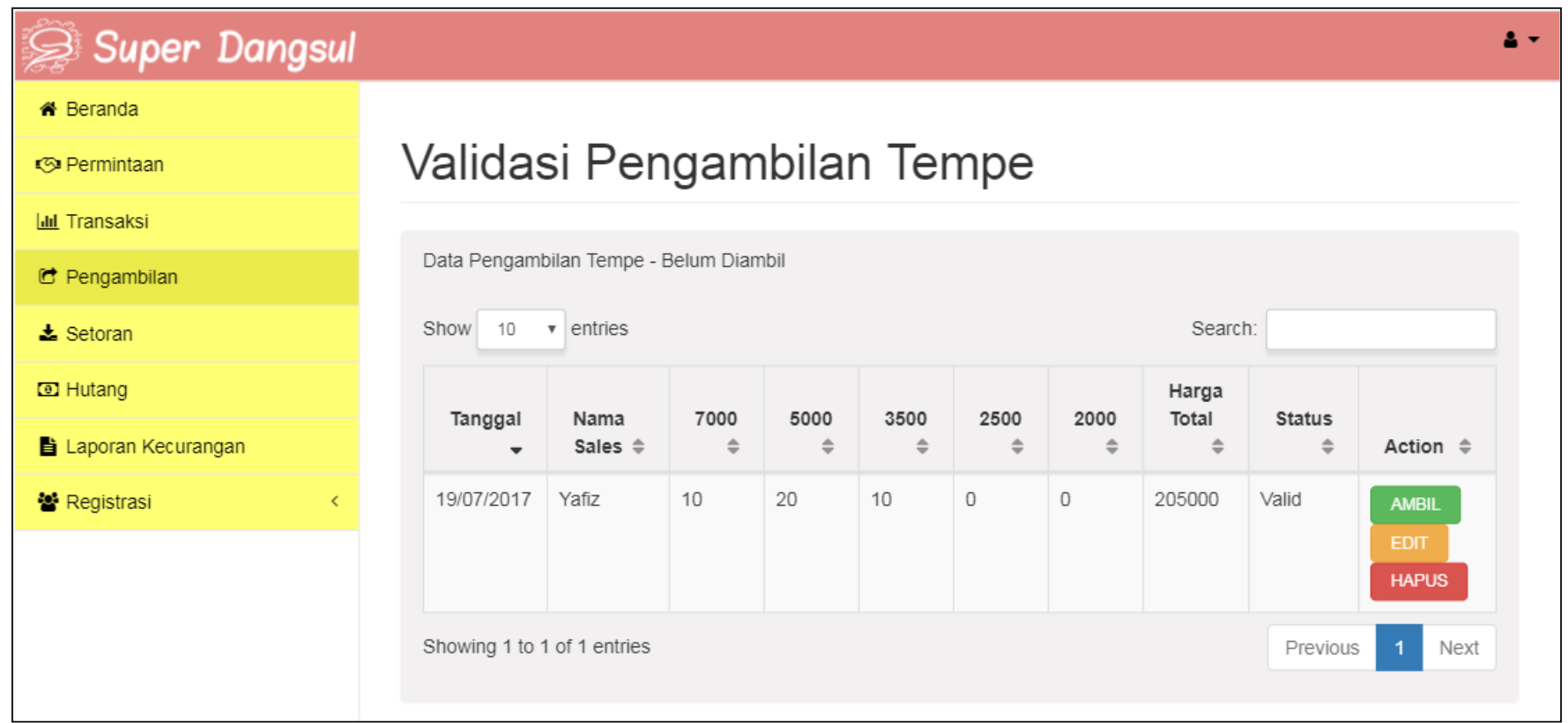

Gambar 12. Validasi pengambilan produk

Kolom search pada Gambar 12 digunakan untuk melakukan pencarian data dengan kata kunci bebas. Dapat dicari per tanggal, nama sales maupun angka-angka yang muncul dan status. Disediakan tiga tombol yakni Ambil, Edit, dan Hapus. Edit digunakan apabila ada permintaan lebih atau kurang dari sales dengan kondisi yang memungkinkan seperti stok masih tersedia atau ada stok sales lain yang dapat dialihkan berdasarkan kesepakatan dengan sales yang bersangkutan.

Setoran penjualan dan pengakuan tagihan ditunjukkan pada Gambar 13

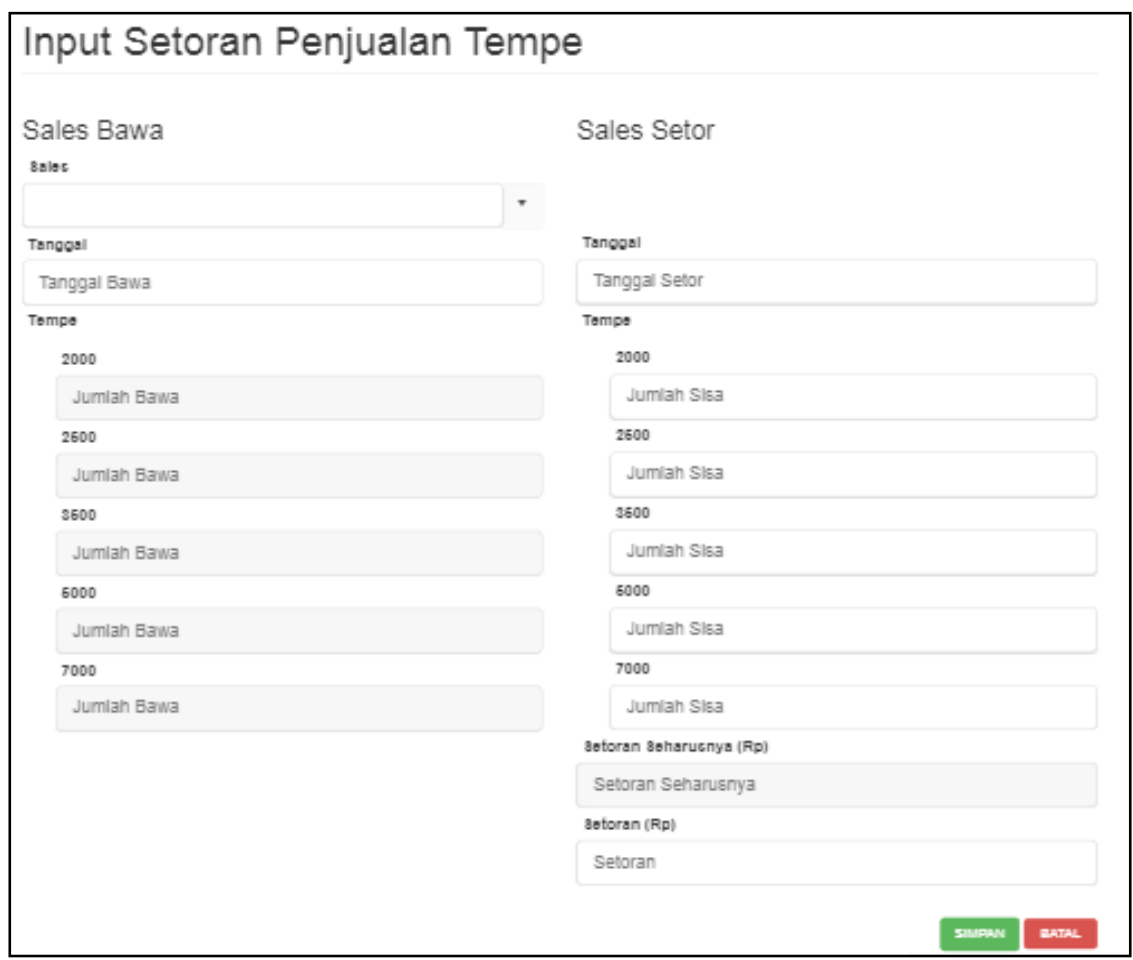

Gambar 13. Setoran penjualan

Ketika sales melakukan setoran disore hari, Ia diberikan informasi mengenai total produk yang dibawa dan mengisikan berapa yang terjual. Transaksi ini akan otomatis menghitung berapa stok yang terjual dan nilai yang ditagihkan. Sebelumnya diuji cobakan sales hanya menginput sisanya saja karena produk sisa dibawa ketika melakukan setoran. Selisih nya saja yang diotomatis akan tetapi masukan dari sales lebih suka dan nyaman jika 
jumlah terjual saja yang diisikan sedangkan sisanya dihitung otomatis. Secara sekilas seolah sama akan tetapi yang dirasakan oleh user berbeda.

Antar muka terakhir yang didemokan adalah pelaporan dan monitoring laporan. Antar muka ini dapat ditunjukkan pada Gambar 14

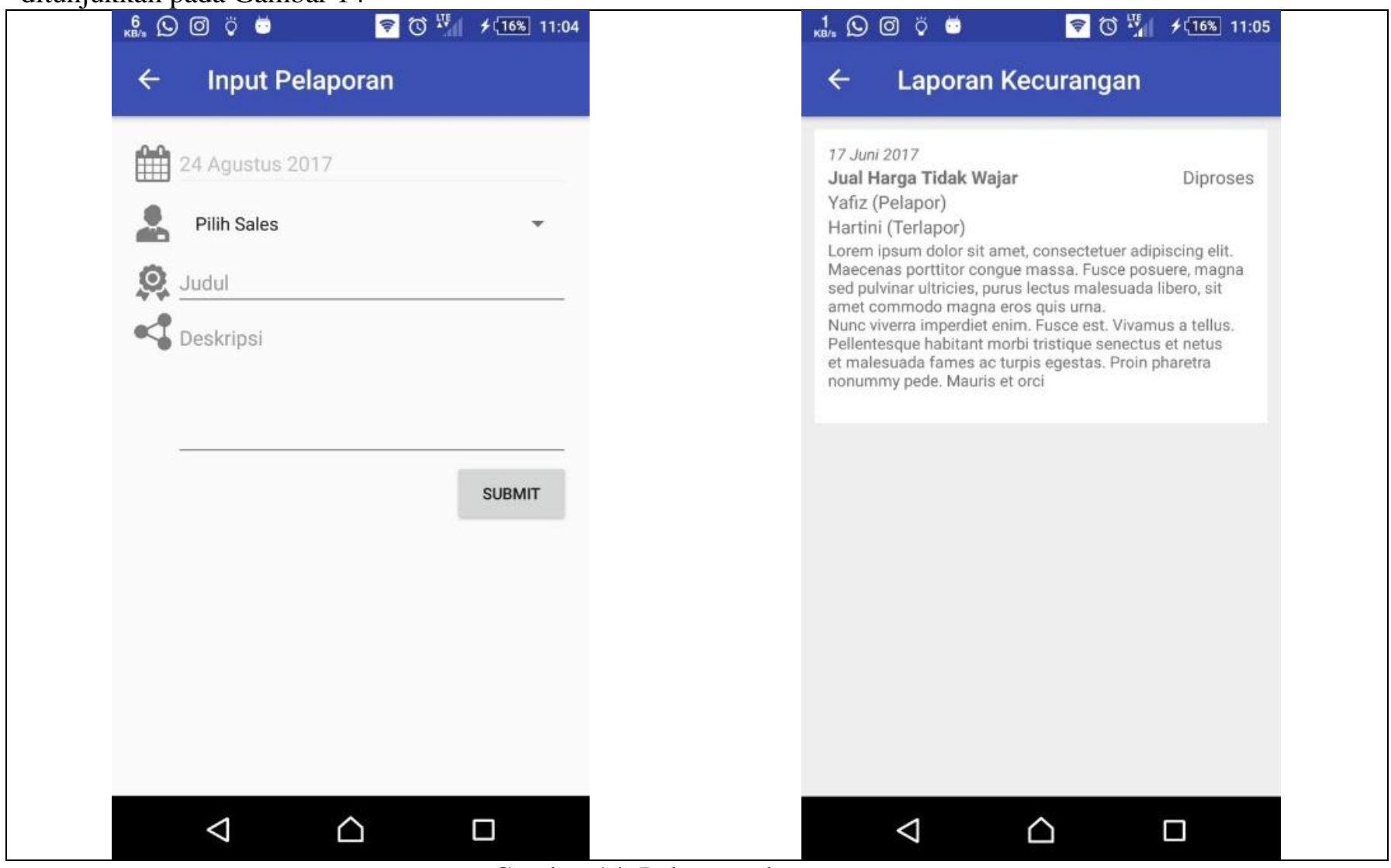

Gambar 14. Pelaporan kecurangan

\section{B. Pengujian perangkat lunak}

Pengujian sistem digunakan untuk menguji apakah sistem berhasil melakukan pengawasan penjualan sales dan memberikan kemudahan pengelolaan sales bagi pemilik. Pengujian perangkat lunak dilakukan dengan metode UAT (User Acceptance Test) [5] dan pengujian fungsional [6][7].

1) Pengujian Pengguna (User Acceptance Test)

Pengujian ini dilakukan dengan cara wawancara. Wawancara dilakukan dengan 4 sumber. Sumber pertama yaitu orang yang menggunakan sistem untuk melakukan pengawasan penjualan sales yaitu pemilik Super Dangsul, Bapak Syahrul. Tiga sumber berikutnya diambil secara acak dari orang yang dikenakan pengawasan oleh pemilik yaitu sales Super Dangsul.

Berdasarkan wawancara dengan pemilik, Ia merasa terbantu dengan adanya sistem monitoring. Pemilik tidak lagi membutuhkan waktu lama dan prosedur berbelit untuk melihat dan menganalisis penjualan sales. Ia juga tidak lagi kesulitan apabila ada hutang setoran yang menumpuk. Semua penjualan sales tersimpan pada sistem sehingga pemilik lebih mudah melakukan monitoring.

Berdasarkan wawancara dengan sales, diperoleh informasi bahwa mereka merasa terbantu dengan adanya aplikasi ini. Sales tidak perlu melakukan pemesanan secara langsung face to face dengan pengepul. Sales dapat melakukan pemesanan tempe melalui aplikasinya. Hutang sales juga tercatat pada aplikasi sehingga memudahkan sales untuk mengingatkan hutang setoran. Selain itu, sales dapat melihat penjualan terdahulu untuk memudahkan dalam mempelajari riwayat penjualan.

Secara keseluruhan pihak UD. Super Dangsul merasa aplikasi telah berjalan sesuai dengan proses bisnis yang ada dan memudahkan dalam melakukan monitoring penjualan sales. Sales juga merasa lebih mudah untuk melakukan pemesanan produk dibanding sebelumnya. 


\section{2) Pengujian fungsionalitas}

Pengujian fungsionalitas dilakukan untuk mengetahui letak kekurangan sistem dengan memberikan berbagai kasus pengujian. Pengujian dilakukan dengan cara memberikan contoh kasus pengujian kemudian diujicobakan pada sistem untuk mengetahui kekurangan sistem. Pengujian diujikan pada fungsi-fungsi yang ada pada sistem. Hasil pengujian dapat dilihat pada Tabel 2.

TABEL 2. PENGUJIAN FUNGSIONAL

\begin{tabular}{|c|c|c|c|}
\hline No & Fungsi & Persentase & Keterangan \\
\hline 1. & Login & $\begin{array}{l}\text { Dari } 4 \text { kasus yang diujikan, } 4 \text { diantarnya } \\
\text { dinyatkakan berhasil. Persentase } \\
\text { keberhasilan adalah } 100 \%\end{array}$ & $\begin{array}{l}4 \text { kasus tersebut menguji validasi } \\
\text { login dengan menginputkan sesuai } \\
\text { kasus inputan. }\end{array}$ \\
\hline 2. & $\begin{array}{l}\text { Manajemen Laporan } \\
\text { Kecurangan }\end{array}$ & $\begin{array}{l}\text { Dari } 2 \text { kasus yang diujikan, } 2 \text { diantarnya } \\
\text { dinyatakan berhasil. Prosentasi } \\
\text { keberhasilan adalah } 100 \%\end{array}$ & $\begin{array}{l}2 \text { kasus tersebut menguji verifikasi } \\
\text { penghapusan laporan dan validasi } \\
\text { laporan. }\end{array}$ \\
\hline 3. & Manajemen Data Admin & $\begin{array}{l}\text { Dari } 7 \text { kasus yang diujikan, } 3 \text { diantarnya } \\
\text { dinyatakan berhasil. Prosentasi } \\
\text { keberhasilan adalah } 42.86 \%\end{array}$ & $\begin{array}{l}7 \text { kasus tersebut menguji } \\
\text { penambahan, edit, dan hapus data } \\
\text { admin. }\end{array}$ \\
\hline 4. & Manajemen Data Sales & \begin{tabular}{|l|} 
Dari 13 kasus yang diujikan, 11 \\
diantaranya dinyatakan berhasil. \\
Prosentase keberhasilan adalah $84.61 \%$
\end{tabular} & $\begin{array}{l}13 \text { kasus tersebut menguji mengenai } \\
\text { penambahan, edit, dan hapus data } \\
\text { sales. }\end{array}$ \\
\hline 5. & Cilil Hutang & $\begin{array}{l}\text { Dari } 4 \text { kasus yang diujikan, } 4 \text { diantaranya } \\
\text { dinyatakan berhasil. Prosentase } \\
\text { keberhasilan adalah } 100 \%\end{array}$ & $\begin{array}{l}4 \text { kasus tersebut menguji inputan } \\
\text { cicilan hutang dan pelunasan hutang. }\end{array}$ \\
\hline 6. & $\begin{array}{l}\text { Manajemen Request } \\
\text { Permintaan Tempe }\end{array}$ & $\begin{array}{l}\text { Dari } 2 \text { kasus yang diujikan, } 2 \text { diantaranya } \\
\text { dinyatakan berhasil. Prosentase } \\
\text { keberhasilan adalah } 100 \%\end{array}$ & $\begin{array}{l}2 \text { kasus tersebut menguji } \\
\text { penambahan dan penghapusan data } \\
\text { request permintaan tempe. }\end{array}$ \\
\hline 7. & $\begin{array}{l}\text { Manajemen Permintaan } \\
\text { Tempe }\end{array}$ & $\begin{array}{l}\text { Dari } 2 \text { kasus uji, } 2 \text { dinyatakan berhasil. } \\
\text { Prosentase berhasil adalah } 100 \%\end{array}$ & $\begin{array}{l}2 \text { kasus tersebut menguji validasi dan } \\
\text { penghapusan data permintaan tempe. }\end{array}$ \\
\hline 8. & $\begin{array}{l}\text { Manajemen Pengambilan } \\
\text { Tempe }\end{array}$ & $\begin{array}{l}\text { Dari } 4 \text { kasus yang diujikan, } 4 \text { diantaranya } \\
\text { dinyatakan berhasil. Prosentase } \\
\text { keberhasilan adalah } 100 \%\end{array}$ & $\begin{array}{l}4 \text { kasus tersebut menguji validasi, } \\
\text { verifikasi hapus dan edit data } \\
\text { pengambilan tempe. }\end{array}$ \\
\hline 9. & Setoran Hutang & $\begin{array}{l}\text { Dari } 5 \text { kasus yang diujikan, } 5 \text { diantaranya } \\
\text { dinyatakan berhasil. Prosentase } \\
\text { keberhasilan adalah } 100 \%\end{array}$ & 5 kasus tersebut menguji \\
\hline
\end{tabular}

Dari Tabel 2. Pengujian Fungsionalitas ditemukan bahwa sistem masih memiliki bug minor pada beberapa form. Bug ini terdapat pada manajemen data admin dan manajemen data sales. Manajemen data admin memiliki bugs pada form penambahan dan ubah data admin. Sedangkan manajemen data sales memiliki bugs pada registrasi dan ubah data sales.

Pada form penambahan dan ubah data admin, terdapat bug di bagian input username dan password. Bug diperbaiki agar inputan username dan password tidak berisi karakter kosong. Sedangkan pada form penambahan dan ubah data sales, terdapat bug pada bagian inputan photo. Bug diperbaiki dengan memberikan validasi inputan pada photo agar inputan berupa file berekstensi jpg/png. Secara keseluruhan sistem sudah dapat digunakan untuk me-monitoring sales. Kekurangan (bug) yang ditemukan telah diperbaiki dan fungsi sistem sudah dapat berjalan sesuai dengan harapan

\section{KESIMPULAN}

Kesimpulan yang dihasilkan berdasarkan penelitian dan pembahasan sistem informasi monitoring penjualan sales ditemukan bahwa (a) berdasarkan pengujian UAT dengan teknik wawancara setelah user menggunakan sistem menunjukkan bahwa sistem dapat memberikan informasi penjualan yang dapat memberikan kemudahan pemilik untuk melakukan pengawasan terhadap sales. (b) sistem juga terbukti memberikan kemudahan bagi pemilik dalam melakukan pengecekan penjualan sales. (c) sales mengakui proses pemesanan, pengambilan, setoran, dan pembayaran hutang dirasa lebih terbuka dan dapat ditelusuri secara mandiri oleh sales. (d) pelaporan 
kecurangan dapat menjaga kredibilitas perusahaan dimata pelanggan. Pemilik mendapat kemudahan dalam melakukan monitoring kepada okdum sales dari praktik kecurangan.

\section{UCAPAN TERIMAKASIH}

Terimakasih kepada Program Studi Informatika, Fakultas Teknologi Industri, Universitas Islam Indonesia yang telah memberikan dukungan dan fasilitas dalam pelaksanaan penelitian ini.

\section{DAFTAR PUSTAKA}

[1] Badan Standardisasi Nasional, "Tempe persembahan Indonesia untuk dunia," bsn, 2012. [Online]. Available: http://www.bsn.go.id/uploads/download/Booklet_tempe-printed21.pdf. [Accessed: 15-Aug-2017].

[2] KBBI, "Wiraniaga," -. [Online]. Available: https://kbbi.web.id/wiraniaga. [Accessed: 15-Aug-2017].

[3] R. S. Pressman, Software Engineering, Fifth. New York: Thomas Casson, 2001.

[4] A. Dennis, B. H. Wixon, and R. M. Roth, System Analysis and Design, Fifth. New: Wiley \& Sons, 2009.

[5] C. Ku, N. Che, K. Mohd, and F. Shahbodin, "Personalized Learning Environment: Alpha Testing, Beta Testing \& User Acceptance Test,” Procedia - Soc. Behav. Sci., vol. 195, pp. 837-843, 2015.

[6] I. Arsie, G. Betta, D. Capriglione, A. Pietrosanto, and P. Sommella, "Functional testing of measurement-based control systems : An application to automotive," Measurement, vol. 54, pp. 222-233, 2014.

[7] A. Grocevs, "The capabilities of automated functional testing of programming assignments," in 2nd International Conference on Higher Education Advances, 2016, vol. 228, no. June, pp. 457-461. 